\title{
INSIGHTS INTO TERTIARY ENGLISH-MAJORED STUDENTS' WRITING SELF-EFFICACY
}

\author{
Tran Quoc Thao ${ }^{1 *}$, Nguyen Hoang Nhat Khanh ${ }^{2}$ \\ ${ }^{1}$ Ho Chi Minh City University of Technology (HUTECH), ${ }^{2}$ The University of Dalat
}

\begin{abstract}
Determining learners' self-efficacy plays a pivotal role in improving their language learning process. In additional, understanding language learners' writing self-efficacy can help to enhance their writing performance. However, EFL learners' writing self-efficacy varies in accordance with their learning contexts. This paper, therefore, aims at presenting a study of the writing self-efficacy of Englishmajored students at the context of The University of Dalat in Lam Dong province, Vietnam. This study involved 179 senior English-majored students in answering closed-ended questionnaires and 15 students in participating in semi-structured interviews. Quantitative data from questionnaire were analyzed using SPSS 20.0 in terms of descriptive statistics, while qualitative data from interviews were analyzed employing the content analysis approach. The results revealed that participants believed that they could write English well in their daily life and perform the writing tasks English in writing classes. Furthermore, participants were found to be self-confident in their writing abilities. The findings of this study are hoped to contribute to a better understanding of English-majored students' writing self-efficacy at the research context and other similar ones. As such, pedagogical implications are suggested for improving the quality of teaching and learning of academic writing based on English-majored students' writing self-efficacy.
\end{abstract}

Keywords: Academic writing; belief; English-majored student; self-efficacy; writing skill

Received: 10/6/2020; Revised: 15/6/2020; Published: 22/6/2020

\section{TÌM HIỂU NIỀM TIN VÀO NĂNG LỰC VIẾT CỦA SINH VIÊN CHUYÊN NGÀNH TIẾNG ANH}

\author{
Trần Quốc Thao ${ }^{*}$, Nguyễn Hoàng Nhật Khanh ${ }^{2}$ \\ ${ }^{I}$ Truờng Đại học Công nghệ Thành phố Hồ Chỉ Minh, ${ }^{2}$ Truò̀ng Đại học Đà Lạt
}

\section{TÓM TẰT}

Niềm tin vào năng lực của bản thân đóng vai trò then chốt trong việc cải thiện quá trình học ngôn ngữ. Hiểu rõ niềm tin vào năng lực viết của người học ngôn ngữ có thể giúp nâng cao khả năng viết của họ. Tuy nhiên, niềm tin vào năng lực viết của người học ngôn ngữ ở các ngữ cảnh khác nhau thì khác nhau. Vì vậy, bài báo này nhằm trình bày nghiên cứu về niềm tin vào năng lực viết của sinh viên chuyên ngành tiếng Anh của trường Đại học Đà Lạt, thuộc tỉnh Lâm Đồng, Việt Nam. Nghiên cứu này có sự tham gia của 179 sinh viển năm cuối chuyên ngành tiếng Anh trong việc trả lời bảng khảo sát và 15 sinh viên tham gia phỏng vấn bán cấu trúc. Dữ liệu định lượng từ bảng câu hỏi được phân tích bằng SPSS 20.0 về mặt thống kê mô tả, trong khi dữ liệu định tính từ các cuộc phỏng vấn được phân tích sử dụng phương pháp phân tích nội dung. Kết quả cho thấy những người tham gia tin rằng họ có thể viết tiếng Anh tốt trong cuộc sống hàng ngày và trong lớp học. Hơn nữa, những người tham gia cũng thể hiện sự tự tin vào khả năng viết của mình. Những phát hiện của nghiên cứu này được hy vọng sẽ góp phần hiểu rõ hơn về những sinh viên năm cuối chuyên ngành tiếng Anh. Như vậy, ý nghĩa sư phạm được đề xuất để cải thiện chất lượng dạy và học viết học thuật dựa trên các sinh viên chuyên ngành tiểng Anh.

Từ khóa: viết học thuật; niềm tin; sinh viên chuyên ngành tiếng Anh; năng lục bản thân; kỹ năng viết

Ngày nhận bài: 10/6/2020; Ngày hoàn thiện: 15/6/2020; Ngày đăng: 22/6/2020

* Corresponding author. Email: tq.thao@hutech.edu.vn

DOI: https://doi.org/10.34238/tnu-jst.3273 


\section{Introduction}

Writing is believed to be the key skill that can contribute much to students' learning success [1]. Additionally, researchers [2], [3], [4] have detected the connection between selfbeliefs and self-efficacy in writing and other variables related to writing and writing outcomes as students' beliefs about themselves as good writers can present a vital role in self-regulated writing [5-6]. Students' beliefs in their writing will vary throughout the writing area, and the sense of self-efficacy varies in prophetic power relying on the task to be predicted. Likewise, self-efficacy has a significant impact on behavior [7-8]. This has wider meanings as proof that students' selfefficacy in their writing are linked to the learning strategies they accept [9]. Writing is also regarded as a powerful and productive skill, and it is a complicated action that needs a particular level of having language knowledge, using writing strategies, enriching new words, and mastering grammar [10-12].

Researchers [13-14] have asserted that selfefficacy has a significant impact on behavior. Likewise, Zimmerman and Bandura [15] have found that the writing self-efficacy is positively correlated with the goals of course performance, satisfaction with potential grades, and actual performance. In addition, the writing self-efficacy provides information about learners' own beliefs about their skills for specific skills such as grammar and mechanics [11]. In another aspect, selfefficacy predicts the success of students in academia and at various levels [11]. Schunk [16] has debated how self-efficacy might work during academic learning. He argues that the initial self-efficacy varies depending on the "aptitude (abilities and attitudes)" and past experiences. Personal factors such as information processing and goal setting as well as situational factors (feedback and rewards for lecturers) affect the students. From these factors, students derive indications of how well they learn to assess the effectiveness of their further learning [16]. Motivation is increased and students, in turn, have a sense of self-efficacy for doing well. Students with the same degree of cognitive ability development may vary in their mental performance being controlled on the ability of their perceived self-efficacy. Thus, personal success and achievements demand not only skills but also the self-efficacy to make good use of these capabilities [17]. Pintrich and DeGroot [18] discuss that students must have both the will and the ability to achieve in the classroom. They have found that perceived self-efficacy predicts the use of cognitive and self-regulatory learning strategies by students in the classroom and that these strategies, in turn, are predictive of academic attainment.

Self-efficacy has important characteristics in learning [19]. First, self-efficacy focuses on assessing performance rather than personal characteristics such as psychological characteristics or physical characteristics. Second, these beliefs are multi-dimensional rather than a single disposition. Therefore, English-language efficacy beliefs may differ from efficacy beliefs in mathematics. In fact, efficacy beliefs are associated with different functional areas. Third, self-efficacy measures are context-dependent. Learning in competitive classrooms may have a lower self-efficacy than in cooperative ones. Thus, the self-efficacy ratings differ with respect to the performance context. Fourth, self-efficacy judgments depend on a performance control criterion rather than normative or other criteria. Performance is judged by the difficulty level of the task, not how well a person is performing compared to others. Finally, self-efficacy judgments relate to future functioning. Beliefs are measured before performing the relevant activities. This former property of self-efficacy places them in a temporal position and plays a causal role in each area, including academic motivation. Bandura [20] has indicated that self-efficacy is formed through four sources, namely mastery experiences, vicarious experiences, verbal or social beliefs, and physiological and emotional states. 
Prior studies relevant to this area have been conducted. Significantly, Hong et al. [21] examined various patterns of writing selfefficacy of EFL students. They affirmed that the characterization of high and average personal efficacy described students spending many times learning English and were too large or too small female in comparison to the low self-efficacy profile. The low selfefficacy profile differed significantly from the mean and high self-efficacy profiles in terms of self-regulated learning strategies and speech interpretation strategies. Additionally, Wang et al. [22] conducted a study on students' self-regulated learning strategies and self-efficacy beliefs in learning English. The study involved 517 non-English majored students in a Chinese university in answering a questionnaire. The results indicated that participants' self-ratings of self-efficacy and use of self-regulated learning strategies were not high. In the context of Vietnam, Phan and Locke [23] carried out a study on Vietnamese EFL teachers' sources of self-efficacy. This study employed journal and observation as the research instruments to collect data from eight teachers. The findings showed that there were four sources of self-efficacy (mastery experiences, social persuasion, vicarious experiences and physiological/affective states). In 2019, Truong and Wang [24] did a study on examining college students' selfefficacy beliefs in learning English as a foreign language. They employed a questionnaire to collect data from 767 first year students. The results indicated that there was a positive relationship between self- efficacy beliefs and English language proficiency, and no difference in self-efficacy beliefs were found in terms of gender.

In brief, it is observed that the focus of selfefficacy has been conducted in different contexts, but the writing self-efficacy has not been substantially examined. Therefore, this study endeavors to explore the writing selfefficacy of English majored students at a tertiary institution in Lam Dong Province, Vietnam. In order to achieve the aforementioned objective, the following research question is addressed: "What beliefs about writing self-efficacy do tertiary English-majored students hold?"

\section{Methodology}

\subsection{Research context and participants}

The mixed methods study was conducted at a Lam Dong based higher institution in Vietnam, which has different faculties. The Faculty of Foreign Languages has two English language training programs namely English Language Education and English Language Studies. English majored students have to learn English language skills (Listening, Speaking, Reading and Writing) within the first two years.

This study involved 179 senior Englishmajored students who were purposively sampled. Table 1 presents general information of the research subjects in terms of gender, age, and hours a day to self-practice writing skill, and the experience of taking an international English test. Among 179 participants, 15 students were purposively invited for semi-structured interview.

Table 1. Research participants' general information

\begin{tabular}{llrr}
\hline & & \multicolumn{2}{c}{$\mathbf{N = 1 7 9}$} \\
\cline { 3 - 4 } Gender & Male & Frequency & \% \\
\hline \multirow{2}{*}{ Age } & Female & 13 & 7.3 \\
& $20-23$ & 166 & 92.7 \\
\hline \multirow{2}{*}{ Self-practicing writing skill / per day } & over 23 & 0 & 100.0 \\
& less than 1 hour & 17 & 0 \\
\hline Experience of taking an international & $1-3$ hours & 142 & 79.3 \\
English test & over 3 hours & 20 & 11.2 \\
\hline
\end{tabular}

http://jst.tnu.edu.vn; Email: jst@tnu.edu.vn 


\subsection{Research instruments}

Two research instruments, namely a closedended questionnaire and semi-structured interview, were used in this study. The former which was adapted from the questionnaire of Wang et al. [22] consists of two sections: Section A: Respondent's demographic information; Section B: Questionnaire content. The main content of questionnaire has 15 closed-ended items asking writing selfefficacy (in daily life: 7 items and in writing classes: 8 items). The five-point Likert scale for the items in writing self-efficacy is from Totally unable to do to Totally able to do. The Cronbach's alpha of the whole questionnaire was .98 . This means that the reliability of the questionnaire was very high. The latter was semi-structured interview which was designed based on the theoretical framework and includes three main questions. The respondents answered the questionnaire and interview questions in their mother tongue so that they did not encounter any language difficulty in expressing their ideas.

\subsection{Procedures for data collection and analysis}

After the questionnaire and interview had been piloted, 200 copies of the official questionnaire were administered to students, but 179 copies were returned. It took them around 15-20 minutes to finish the questionnaire. Then, 15 students were purposively invited for semi-structured interviews. Each interview lasted from 20-25 minutes. All the interviews were recorded for latter analysis.

With respect to data analysis, the quantitative data from questionnaires were analyzed by SPSS in terms of mean and standard deviation, while the qualitative data from interviews, the content analysis was employed for data analysis. The interval mean scores were interpreted as 1.00 - 1.80: Totally unable to do; 1.81 - 2.60: Unable to do; .61 - 3.40: Possibly able to do; 3.41 - 4.20: Able to do; 4.21 - 5.00: Totally able to do well. Interviewees were coded as $\mathrm{S} 1, \mathrm{~S} 2$ to $\mathrm{S} 15$. In order to valid the data analysis, two interraters were invited for re-analysing the three randomly chosen pieces of data. The level of agreement among inter-raters had to be at least $95 \%$.

\section{Results and discussion}

\subsection{Results}

3.1.1. English-majored students' writing selfefficacy in daily life

Table 2 reveals that the overall mean score of English-majored students' writing self-efficacy in daily life is 4.37 (out of 5). This can be interpreted that English-majored students believed that they were totally able to write English in their daily life. It is further noticed that the standard deviations were relatively large, which means that many students were not really able to write English well.

Specifically, participants could do well in writing English such as "[composed] messages in English on the Internet (Facebook, Twitter, blogs, etc.)" and (item 1: $\mathrm{M}=4.40 ; \mathrm{SD}=.97$ ) and "[left] a note for another student in English" (item 3: $\mathrm{M}=4.40$; $\mathrm{SD}=.97)$. In addition, participants were able to write "e-mails in English" (item 4: $\mathrm{M}=$ 4.39; $\mathrm{SD}=1.09$ ), "an invitation to a friend for a party" (item 6: $\mathrm{M}=4.39$; $\mathrm{SD}=1.09$ ), "a good report" (item 7: $\mathrm{M}=4.37$; $\mathrm{SD}=1.02$ ), "a text in English" (item 2: $\mathrm{M}=4.34 ; \mathrm{SD}=1.10$ ) and "diary entries in English" (item 5: $\mathrm{M}=$ 4.34; $\mathrm{SD}=1.01$ ). The scores of standard deviation were very large. It could be understood that participants' writing selfefficacy in daily life was scattered. 
Table 2. English-majored students' writing self-efficacy in daily life

\begin{tabular}{llrr}
\hline \multirow{2}{*}{ No } & \multirow{2}{*}{ Item } & \multicolumn{2}{c}{$\mathbf{N = 1 7 9}$} \\
\cline { 3 - 4 } & & $\mathbf{M}$ & \multicolumn{1}{c}{ SD } \\
\hline $\mathbf{1}$ & I compose messages in English on the Internet (Facebook, Twitter, blogs, etc.) & 4.40 & .97 \\
$\mathbf{2}$ & I write a text in English. & 4.34 & 1.10 \\
$\mathbf{3}$ & I leave a note for another student in English. & 4.40 & .97 \\
$\mathbf{4}$ & I write e-mails in English. & 4.39 & 1.00 \\
$\mathbf{5}$ & I write diary entries in English. & 4.34 & 1.09 \\
$\mathbf{6}$ & I write an invitation to a friend for a party. & 4.38 & 1.01 \\
$\mathbf{7}$ & I write a good report. $\quad$ Total & 4.37 & 1.02 \\
& & $\mathbf{4 . 3 7}$ & $\mathbf{1 . 0 2}$ \\
\hline
\end{tabular}

Note: $M=$ mean $; S D=$ Standard deviation

With respect to the findings from the semistructured interviews, it was found that interviewees had high writing self-efficacy beliefs in their daily life. They reported that they usually did their writing in English outside a class such as writing letters, writing a diary and joining online discussions. Some particular examples are as follows:

...I like writing a diary. Not only would this be a keepsake to reflect on many years down the line, but I will be able to practice my writing in English. Set my goals for the week, try to achieve them and then write what I did that week. (S4)

...I join online discussions to discuss some courserelated questions that can help me analyze material, clarify commonalities and differences, and answer other students' entries.... (S10)

Moreover, participants shared that they could write in English in daily life because they practiced writing a lot. They could use formal constructions and high-level vocabulary, and they always consulted a good dictionary to choose proper words. In addition, they affirmed that being good at writing meant choosing the right words and not filling the entire page. In a like manner, an interviewee stated that he was confidence in his writing because he could identify and practice the writing of sentences, correct common sentence types, practice the writing of many sentence types as well as avoid some common mistakes. For example, some students described as below:
...I am good at writing because I can identify and practice writing sentences, recognize and correct common types of sentences, recognize and practice writing many types of sentences as well as avoid some common mistakes. (S6)

I am good at writing because I can use formal constructions and high-level vocabulary and always consult a good dictionary to choose the proper word. (S12)

3.1.2 English-majored students' writing selfefficacy in writing class

As illustrated in Table 3 about Englishmajored students' writing self-efficacy in writing class, participants were totally able to write "reflections" (item 11: $\mathrm{M}=4.39$; $\mathrm{SD}=$ .97), "long sentences such as compound/complex sentences" (item 12: $\mathrm{M}=$ 4.38; $\mathrm{SD}=.1 .00$ ), "messages" (item 9: $\mathrm{M}=$ 4.35; $\mathrm{SD}=1.05)$ "in English, "keep writing even when it is difficult" (item 14: $\mathrm{M}=4.37$; $\mathrm{SD}=1.01$ ), and "form new sentences from words [they] have just learnt" (item 14: $\mathrm{M}=$ 4.35; $\mathrm{SD}=1.07)$. In addition, participants could "write essays in English" (item 10: M = 3.39; $\mathrm{SD}=1.54$ ) and "do writing assignments at the last minute and still get a good grade" (item 13: $\mathrm{M}=3.43 ; \mathrm{SD}=1.17$ ). Nonetheless, they were possibly able to "make English sentences with idiomatic phrases" (item 8: M $=3.31$; $\mathrm{SD}=1.20$ ). Regarding the scores of standard deviation, they are quite large. This means that there were gaps among participants' answers. 
Table 3. English-majored students' writing self-efficacy in writing class

\begin{tabular}{clrr}
\hline \multirow{2}{*}{ No } & \multicolumn{1}{c}{ Item } & \multicolumn{2}{c}{$\mathbf{n = 1 7 9}$} \\
\cline { 3 - 4 } & & $\mathbf{M}$ & \multicolumn{1}{c}{ SD } \\
\hline $\mathbf{8}$ & I make English sentences with idiomatic phrases. & 3.31 & 1.20 \\
$\mathbf{9}$ & I write messages in English. & 4.35 & 1.05 \\
$\mathbf{1 0}$ & I write essays in English. & 3.98 & 1.54 \\
$\mathbf{1 1}$ & I write reflections in English. & 4.39 & .97 \\
$\mathbf{1 2}$ & I write long sentences such as compound/complex sentences in English. & 4.38 & 1.00 \\
$\mathbf{1 3}$ & I do writing assignments at the last minute and still get a good grade. & 3.43 & 1.17 \\
$\mathbf{1 4}$ & I keep writing even when it is difficult. & 4.37 & 1.01 \\
$\mathbf{1 5}$ & I form new sentences from words I have just learnt. & 4.35 & 1.07 \\
& Total & $\mathbf{4 . 0 7}$ & $\mathbf{1 . 1 3}$ \\
\hline
\end{tabular}

Note: $M=$ mean; $S D=$ Standard deviation

The findings from the in-depth interviews demonstrated that English-majored students were totally confident in writing in classes because they got good grades on essays that they wrote as well as their lectures helped them to correct their essays. Some particular examples are as follows:

...the more you practice believing in yourself, the bigger that belief becomes, so I believe in what I have written, and I often get good grades on essays that I wrote. (S9)

...I practiced writing a lot of essays, and then my lecturers helped me to correct them, so I believe I'm good at writing. (S2)

Similarly, some students claimed that they were very confident in writing essays at the university because of their careful preparation and caution. Besides, they could keep writing even when it was difficult.

... People would be impressed to say that I could write an essay of 2,000 words in less than an hour, but what they don't know was how much preparation had been done up to that point. Therefore, I am very confident in my essays, and I can keep writing even when it's difficult. (S5)

...when I write something down, I use caution to choose the right words. This means that I write more eloquent, concise and elegant, so I can write well. (S14)

Moreover, a large number of interviewees predicated that they had never been scared of having their writing evaluated by their peers and marked by their lecturers.
...I feel less pressured and more relaxed when doing peer review. The useful advice of my peers is easy to use to revise essay, and I am able to do more discussion and practices. (S8)

...being evaluated by my peers and marked by my lecturers means giving detailed feedback. Therefore, I can improve my grades throughout my educational journey. (S11)

\subsection{Discussion}

This study revealed some major findings. Participants strongly believed that they could write well in English. This finding was not in alignment with that of studies conducted by Hong et al. [21] who have found that their research participants did not have a strong belief in writing self-efficacy. The observed difference is that this study did not examine the correlation between participants' writing self-efficacy with their writing ability. In addition, this study focused on Englishmajored students. Therefore, it could be inferred that the frequent practice of writing may contribute to the high self-efficacy in learners, which may positively influence on learners' self-practice of writing. This is supported by Bandura [20] who have postulated that those with high self-efficacy believe that they can perform well, and he has highlighted that confidence in one's capacity is a useful predictor of efficiency.

With respect to the writing in daily life, participants were strongly confident that they were totally able to write well. One of the 
possible explanations for this may be that participants were majoring in English, so they had a wide range of chances to practice their writing skills at different occasions in their daily life. Furthermore, many participants $(90.5 \%)$ in this study allocated at least 1 hour per day to their self-practice of writing skill.

In respect of the writing in academic class, participants self-reported they were able to write different academic genres in class. This finding may be due to some reasons that they may quite familiar with academic writing and they may understand academic writing genres well as they may have to write frequently in academic classes. What is more, because participants were the fourth-year students, their higher level of writing self-efficacy beliefs may show good training and experience in English writing skills. Therefore, they were confident in appraising their writing capabilities. Notwithstanding, participants' self-efficacy in academic writing seemed equally as the scores of standard deviation were scattered. This may infer that some may believe strongly in their academic writing, while others may have low confidence in their academic writing.

\section{Conclusion}

This study indicated that English majored students believed in their writing self-efficacy in both daily and academic tasks in English, and the high self-efficacy can be a significant predictor in identifying the students' writing achievement. Such a conclusion can draw up some implications. Firstly, teachers should understand their students' self-efficacy well so that they can predict their students' writing skills and provide them with different writing activities in daily life and academic class. Secondly, students should be trained how to use self-regulated writing strategies effectively as they have high self-efficacy in writing, so it is rationale for them to be determined in improving their writing skills in terms of self-practice. Thirdly, students should be provided with appropriate learning materials to self-practice their writing skills. This study cannot avoid some limitations. Its focus mainly lies on the English-majored students' self-efficacy in writing. Additionally, the research instruments were questionnaire and semi-structured interview.

\section{REFERENCES}

[1]. A. Lerstorm, "Speaking across the curriculum; Moving toward shared responsibility?" Paper presented at the Annual Meeting of the Conference on College Composition and Communication, Chicago, IL, 1990.

[2]. L. Flower and J. R. Hayes, "A cognitive process theory of writing," College Composition and Communication, vol. 32, pp. 365-387, 1981.

[3]. M. Scardamalia, C. Bereiter and H. Goleman, "The role of production factors in writing ability," in What writers know: The language, process, and structure of written discourse, M. Nystrand, Ed. New York: Academic, 1982, pp. 173-210.

[4]. G. Hull and M. Rose, "Rethinking remediation: Toward a social-cognitive understanding of problematic reading and writing," Written Communication, vol. 6, pp. 139-154, 1989.

[5]. B. K. Hofer, S. L. Yu and P. R. Pintrich, "Teaching college students to be self-regulated learners," in Self-regulated learning: From teaching to self-reflective practice, D. H. Schunk and B. J. Zimmerman, Eds. New York: Guilford Press, 1998, pp. 57-85.

[6]. F. Pajares and Y.F. Cheong, "Achievement goal orientations in writing: A developmental perspective," International Journal of Educational Research, vol. 39, pp. 437-455, 2003.

[7]. D. H. Schunk, "Social cognitive theory and self-regulated learning," in Self-regulated learning and academic achievement theory, research, and practice progress in cognitive development research, B. J. Zimmerman and D. H. Schunk, Eds. New York: SpringerVerlag, 1989, pp. 83-110.

[8]. B. Zimmerman, "Self-efficacy: An essential motive to learn," Contemporary Educational Psychology, vol. 25, pp. 82-91, 2000. 
[9]. M. Prat-Sala and P. Redford, "Does selfefficacy matters? The relationship between self-efficacy in reading and in writing and undergraduate students' performance in essay writing," Educational Psychology, vol. 32, pp. 9-20, 2012.

[10]. T. M. Duong and S. Seepho, "Implementing a portfolio-based learner autonomy development model in an EFL writing course," Suranaree Journal of Social Science, vol. 11, no.1, pp. 29-46, 2017.

[11]. F. Pajares, M. Johnson and E. Usher, "Sources of writing self-efficacy beliefs of elementary, middle, and high school students," Research in the Teaching of English, vol. 42, no.1, pp. 104-120, 2007.

[12]. F. Pajares and Y. F. Cheong, "Achievement goal orientations in writing: A developmental perspective," International Journal of Educational Research, vol. 39, pp. 437-455, 2003.

[13]. D. H. Schunk, "Social cognitive theory and self-regulated learning," in Self-remdateci leamina and academic achievement: Theory, research and practice, B. J. Zimrnernan and D. H. Schunk, Eds. New York: SpringerVerlag, 1989, pp. 83- 110.

[14]. B. Zimmerman, "Self-efficacy: An essential motive to learn," Contemporary Educational Psychology, vol. 25, pp. 82-91, 2000.

[15]. B. Zimmerman and A. Bandura, "Impact of self-regulatory influences on writing course attainment," American Education Research Journal, vol. 31, pp. 845-862, 1994.

[16]. D. Schunk, "Self-efficacy and academic motivation," Educational Psychologist, vol. 26, pp. 207-231, 1991.

[17]. A. Bandura, "Perceived self-efficacy in cognitive development and functioning,"
Educational Psychologist, vol. 28, no.2, pp. 117-148, 1993.

[18]. P. R. Pintrich and E. V. DeGroot, "Motivational and self-regulated learning components of classroom academic performance," Journal of Educational Psychology, vol. 82, pp. 33-40, 1990.

[19]. B. J. Zimmerman, "Self-efficacy and educational development," in Self-efficacy in changing societies, A. Bandura, Ed. New York: Cambridge University Press, 1990, pp.202-231.

[20]. A. Bandura, "Exercise of personal and collective efficacy in changing societies," in Self-efficacy in changing societies, A. Bandura, Ed. New York: Cambridge University Press, 1995, pp.1-45.

[21]. K. C. Hong, C. Wang, M. Bong, and S. A. Hyun, "Examining measurement properties of an English Self-Efficacy scale for English language learners in Korea," International Journal of Educational Research, vol. 59, pp. 24-34, 2013.

[22]. C. Wang, J. Hu, G. Zhang, Y. Chang and Y. $\mathrm{Xu}$, "Chinese college students' self-regulated learning strategies and self-efficacy beliefs in learning English as a foreign language," Journal of Research in Education, vol. 22, no.2, pp. 103-135, 2012.

[23]. N. T. T. Phan and T. Locke, "Sources of selfefficacy of Vietnamese EFL teachers: A qualitative study," Teaching and Teacher Education, vol. 52, pp. 73-82, 2015.

[24]. T. N. N. Truong and C. Wang, "Understanding Vietnamese college students' self-efficacy beliefs in learning English as a foreign language," System, vol. 84, pp. 123$132,2019$. 